\title{
NEW DESIGN OF THE BALTRUM DUNE REVETMENT BASED ON HYDRAULIC MODEL TESTS
}

\author{
Frank Thorenz ${ }^{1}$, Holger Blum² and Andreas Kortenhaus ${ }^{3}$
}

\begin{abstract}
The sandy barrier island of Baltrum is located in the north-western part of the German Federal State Lower Saxony in the North Sea. The north-western part of the island is protected by a dune revetment against storm surges and erosion. In order to determine the functionality and loading of the construction under design storm surge conditions and investigate planning alternatives, numerical modeling of sea state conditions in combination with hydraulical model tests for the construction were executed. Measured overtopping rates of up to $125 \mathrm{l} /\left(\mathrm{s}^{\mathrm{m}} \mathrm{m}\right)$ and loads up to $150 \mathrm{kPa}$ showed the necessity to strengthen and heighten the initial construction. A combination of wall elements for wave run-up and overtopping reduction in combination with a crest wall were designed in order to meet the technical demands of coastal defence as well as the touristical needs of an important recreation locality.
\end{abstract}

Keywords: dune revetment, wave return wall, hydraulic model tests, overtopping

\section{INTRODUCTION}

The island of Baltrum is one of seven inhabited islands located in front of the German mainland coast in the North Sea between the Ems and Weser Estuary (Fig. 1). These sandy barrier islands, comprising mainly of dunes in the north and salt marshes in the south, are part of the Wadden Sea, which stretches from the Netherlands to Denmark. The islands and the Wadden Sea form a morphological system consisting of islands, tidal inlets, ebb-deltas, tidal flats and tidal gullies. Complex hydro-morphological processes induced by tides, waves, storm surges and wind surges occur. All islands have an important economical function as strongly frequented sea resorts in north-western Germany.

The coastal defence system for the island is stated in the Master Plan Coastal Defence for the Federal State of Lower Saxony. A dune revetment of $1.9 \mathrm{~km}$ length and 14 groins protect the inhabited north-western part of Baltrum against storm surges and erosion. The coastal defence strategy for this part of the island is safeguarding the existing coastal defence line (NLWKN, 2010). Coastal defence for the East Friesian Islands is a task of the Federal State of Lower Saxony, executed by the Lower Saxony Water Management, Coastal Defence and Nature Conservation Agency (NLWKN).

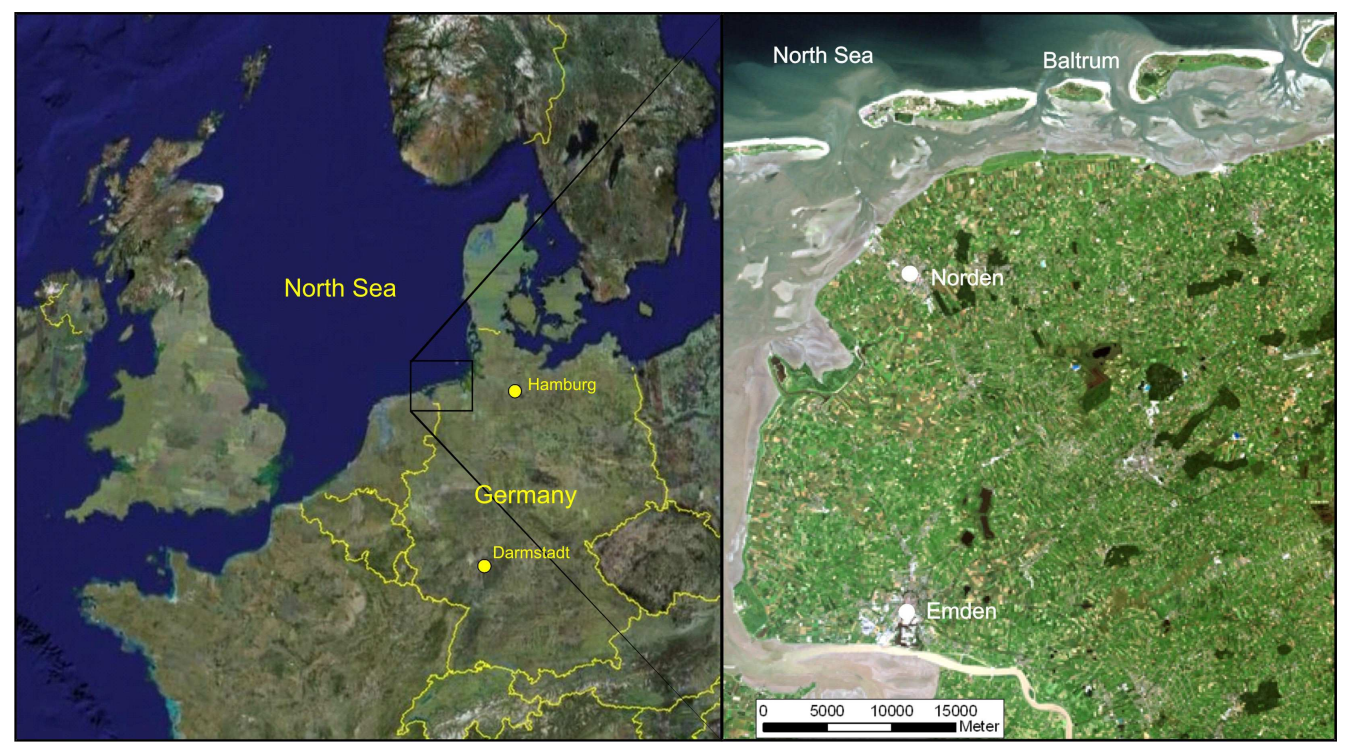

Figure 1. Overview - Location of the island of Baltrum.

\footnotetext{
${ }^{1}$ Lower Saxony Water Management, Coastal Defence and Nature Conservation Agency (NLWKN), Jahnstrasse 1, 26506 Norden, Germany

${ }^{2}$ Lower Saxony Water Management, Coastal Defence and Nature Conservation Agency (NLWKN), Jahnstrasse 1, 26506 Norden, Germany

${ }^{3}$ Leichtweiß-Institut für Wasserbau, Technical University Braunschweig, Beethovenstrasse 51a, 38106 Braunschweig, Germany
} 
In order to apply a security check for the construction, sea state conditions for design water level, wave run-up, wave overtopping and wave loadings of the sea wall were investigated by application of numerical and hydraulical model tests. Results showed the need to heighten and strengthen the construction over a length of more than $1 \mathrm{~km}$. Due to the nearness of settlements, partially limited space for extension of the construction was available. Based on numerical and hydraulical model tests, wave run-up and overtopping reduction wall elements in combination with a crest wall were designed in order to reach coastal defence requirements. Since the dune revetment is intensively used as a promenade by tourists, these demands have to be considered.

\section{INITIAL SITUATION}

The initial sea wall construction consists of a 1:4 sloped rip-rap dune revetment built in 1974/1990, an asphalt berm, a vertical concrete wall with a crest height of $7.9 \mathrm{~m} \mathrm{NN}$ (German datum) and an adjacent pavement. For an approx. $440 \mathrm{~m}$ long stretch, settlements are located very close to the construction (Fig. 2). The first coastal defence constructions for this part of Baltrum were constructed in 1872/73. Due to ongoing erosion and damages by storm surges, several new constructions have been built (Erchinger and Ukena, 1987). The design water level for the coastal defence structures at Baltrum is determined to a level of $5.30 \mathrm{~m} \mathrm{NN}$ according to the Master Plan Coastal Defence. This level is located close to the base point of the berm. Ten year moving average high water level amounts to $1.23 \mathrm{~m} \mathrm{NN}$.

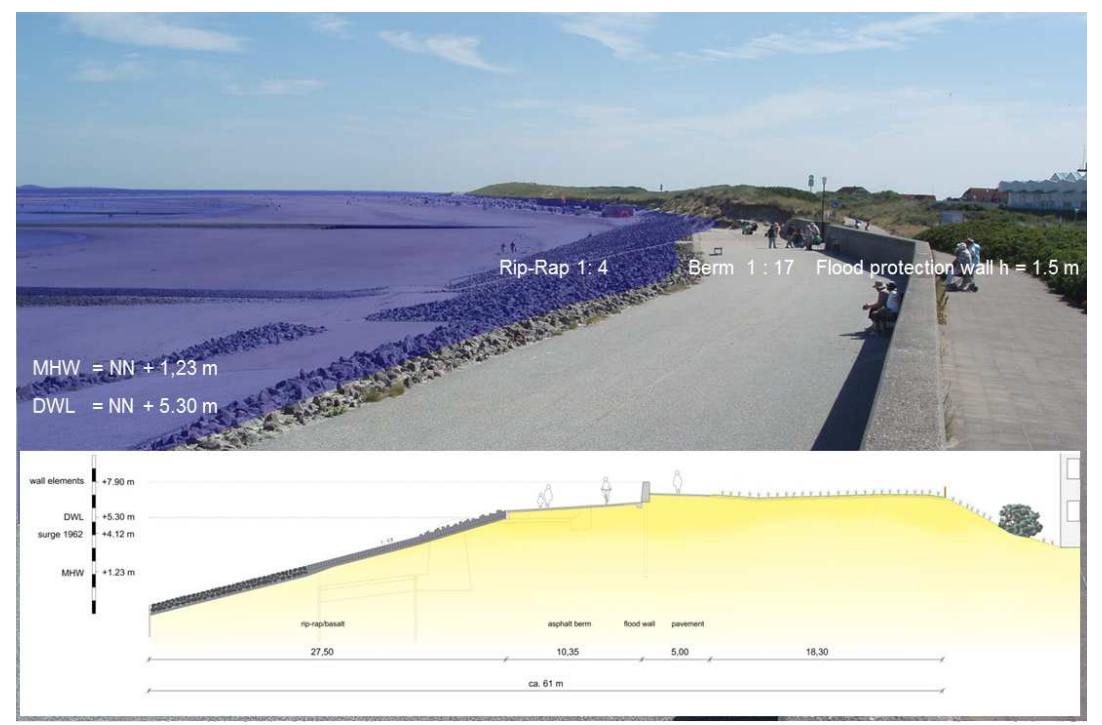

Figure 2. Cross section and photograph of the Baltrum dune revetment.

\section{OBJECTIVES AND OUTLINE OF INVESTIGATIONS}

The functionality of the dune revetment is considerably dependent from the hydro-morphological boundary conditions. Here the shape ebb-delta of the Baltrum tidal inlet marks a main influencing, highly dynamic morphological element as well for design wave climate as for sediment supply of the north-western part of the island.

Main objectives of investigation were to determine:

- Design wave climate for design water level of $5.30 \mathrm{~m} \mathrm{NN}$ including a safety factor for sea level rise of $50 \mathrm{~cm}$.

- Wave run-up and wave overtopping of the initial and planned construction.

- Loading of the initial and planned construction.

Due to the complex geometry of the construction, in preliminary studies was shown, that wave runup and overtopping as well as loading cannot be calculated with an adequate accuracy by standard deterministic calculation formula (Blum et al. 2008). In the first investigation phase design wave climate was determined with a numerical wave model. Based on the modeling results, the initial state of the revetment as well as selected planning alternatives were investigated by means of hydraulical model tests. 


\section{Numerical modeling of sea state conditions}

Design wave heights $\mathrm{H}_{\mathrm{s}}$ and wave periods $\mathrm{T}_{\mathrm{m}-1,0}$ for the revetment were calculated by application the phased averaged numerical wave model SWAN. A regional curved linear grid model of the coastal area covers an extension of ca. $35 \times 20 \mathrm{~km}$ and spatial resolution of $40 \mathrm{~m}$ to $240 \mathrm{~m}$. The detailed model of the Baltrum foreshore has a resolution between $9 \mathrm{~m}$ and $2 \mathrm{~m}$. As seaward boundary condition a JONSWAP spectrum with $\mathrm{H}_{\mathrm{m} 0}=10 \mathrm{~m}, \mathrm{~T}_{\mathrm{p}}=15 \mathrm{~s}$ and $\mathrm{T}_{\mathrm{m}}=12 \mathrm{~s}$ and a constant wind field with $\mathrm{u}=30 \mathrm{~m} / \mathrm{s}$ and $\mathrm{R}=315^{\circ}$ was used. In order to consider the effects of morphological changes of the ebb delta and the foreshore, selected morphological conditions were taken into account. Calculated design wave heights (Fig. 3) and wave periods amount to $\mathrm{H}_{\mathrm{m} 0}=3.05 \mathrm{~m}$ and $\mathrm{T}_{\mathrm{m}-1,0}=10.25 \mathrm{~s}$ (Kaiser 2008).

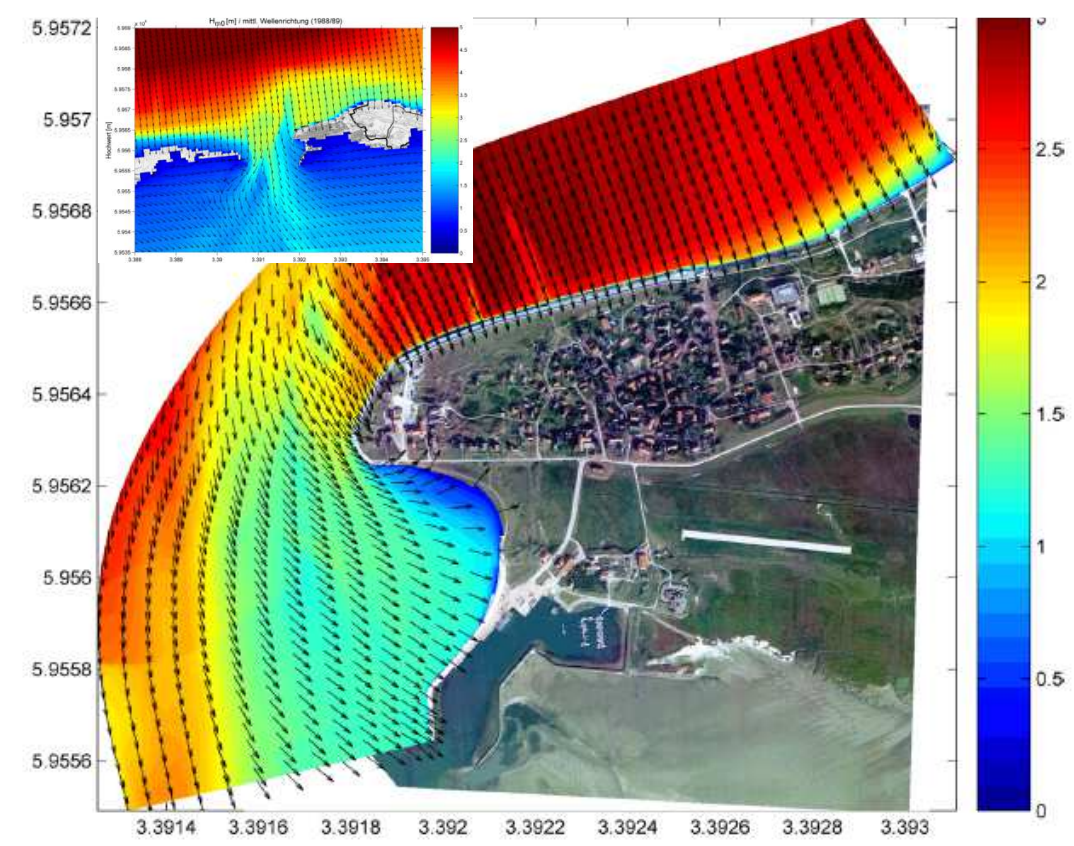

Figure 3. Design wave heights $H_{m 0}$ for the north-western part of Baltrum (Kaiser 2008).

\section{Hydraulical model tests}

Considering design conditions, for the initial state of the revetment freeboards $R_{c} / H_{s}$ between 1.12 and 1.23 have been calculated. The performance of the construction for design conditions was investigated in an hydraulical model scaled $1: 10$ by the Leichtweiss-Institute of the Technical University of Braunschweig (LWI). The results showed that design conditions will lead to significant wave overtopping up to $125 \mathrm{l} /(\mathrm{s} \cdot \mathrm{m}$ ) (Blum et al. 2008) and maximum pressures of up $150 \mathrm{kPa}$ (Oumeraci et al. 2011) at the existing wall. Overtopping volumes can cause significant flooding of the settlements protected by the revetment. Due to determined pressures the stability of the vertical wall is not ensured. As a consequence, the extension and depth of flooding of the Baltrum settlements in case of failure of the wall increase significantly. Hence a strengthening and heightening of the upper part of the structure is necessary in order to guarantee functionality and stability of the construction under design conditions and limit overtopping volumes to an acceptable amount.

In order to optimize the functional design, alternative feasible layouts of the upper part of the revetment aiming at significant reduction of wave overtopping, taken the limited planning space into account, are investigated by means of hydraulic model tests in two different scales:

Within a first investigation phase, model tests with a scale factor of 50 were performed in a small wave flume sized $20.0 \mathrm{~m} \times 0.3 \mathrm{~m} \times 0.38 \mathrm{~m}$, using regular waves. These test aim at qualitative comparison of six alternative cross sections in order to determine the most effective construction with respect to overtopping reduction. Additionally a video documentation was executed. The constructions investigated consisted of different combinations of vertical wall elements, slopes and closed vertical walls with a crest wall of $1.0 \mathrm{~m}$ height and a similar, equal crest height of $10.20 \mathrm{~m} \mathrm{NN}$. These alternatives were planned considering aspects of wave-overtopping performance, maintenance and touristical and urban requirements. Three general types of alternatives can be distinguished (Fig. 4): 
- Varying slopes between berm and crest wall (profiles 1, 3 and 5).

- A vertical wall with heights of $1.2 \mathrm{~m}$ and $1.5 \mathrm{~m}$ close to the berm in combination with a mild slope (profiles $2 \mathrm{a}$ and $2 \mathrm{~b}$ ).

- Varying slopes in combination with $1.5 \mathrm{~m}$ long and $0.5 \mathrm{~m}$ high vertical wall elements, spaced $0.5 \mathrm{~m}$ (profile 4).
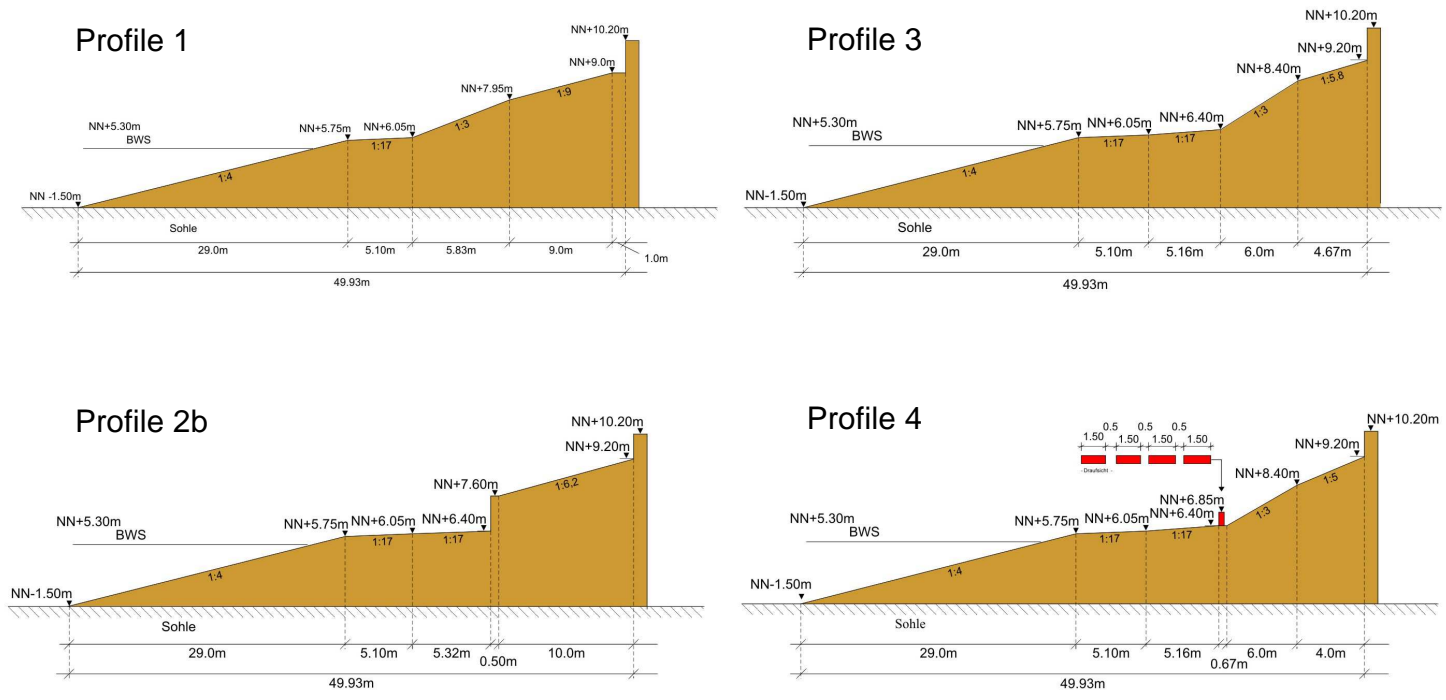

Figure 4. Selection of profiles investigated in small scale model tests.

Significant differences in resulting wave overtopping were found. Profiles $2 \mathrm{a}$ and $2 \mathrm{~b}$ showed relatively small overtopping rates, which are mainly induced by the vertical wall in the middle of the profile. Wave energy is dissipated by wave breaking and reflection, leading to a significant reduction of wave run-up and overtopping, whereas the higher wall in profile $2 \mathrm{~b}$ in comparison to profile $2 \mathrm{a}$ consequently leads to a smaller overtopping rate. Due to breaking waves and the location of the base point of the wall only $1.1 \mathrm{~m}$ above design water level, pressure shocks at the wall can be expected, like they were measured in model tests for a similar situation at the Norderney dune revetment (Thorenz and Blum 2011). Profile 4 also shows a significant overtopping reduction, more effective than profile $2 \mathrm{a}$ and less than profile $2 \mathrm{~b}$. Highest overtopping rates, up to power of ten higher than profile $2 \mathrm{a}$, showed the alternatives consisting only of slopes between berm and crest wall (Fig. 5). These alternatives do not fulfill the requirements of significant overtopping reduction. As the most sustainable solution, taking functional as well as urban requirements into account, profile 4 was chosen for further detailed investigations.

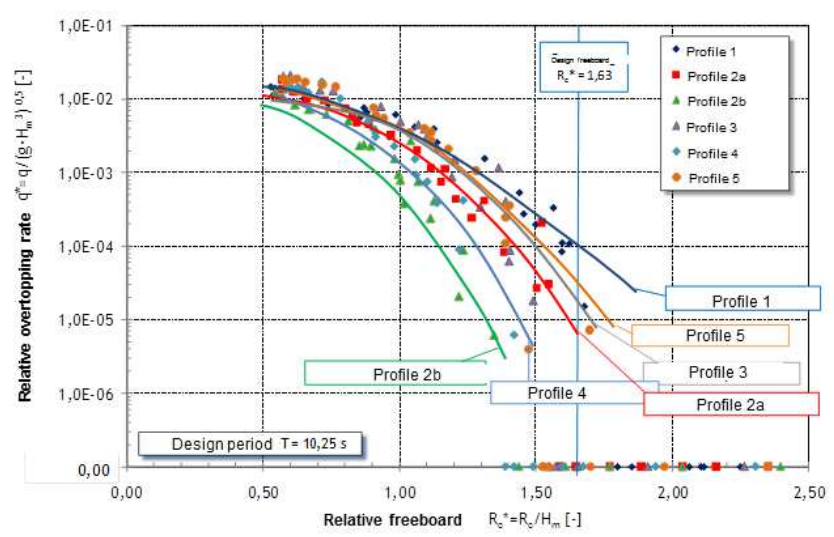

Figure 5. Wave overtopping results for investigated cross section alternatives in 1:50 (Liebisch et al. (2011). 
In the second phase of the model tests, the selected profile 4 has been further investigated in a scale factor of 15 , in order to optimize the profile and to determine wave overtopping and loading of significant elements of the construction. The model test were carried out in the LWI twin wave-flume with $90 \mathrm{~m}$ length and $1.25 \mathrm{~m}$ depth, consisting of 2 parallel flumes of $1 \mathrm{~m}$ and $2 \mathrm{~m}$ width (Fig. 6). These flumes can be operated in single or twin mode. Solitary, regular, and random waves can be generated up to about $30 \mathrm{~cm}$ wave height using a piston-type wave maker with active wave absorption.

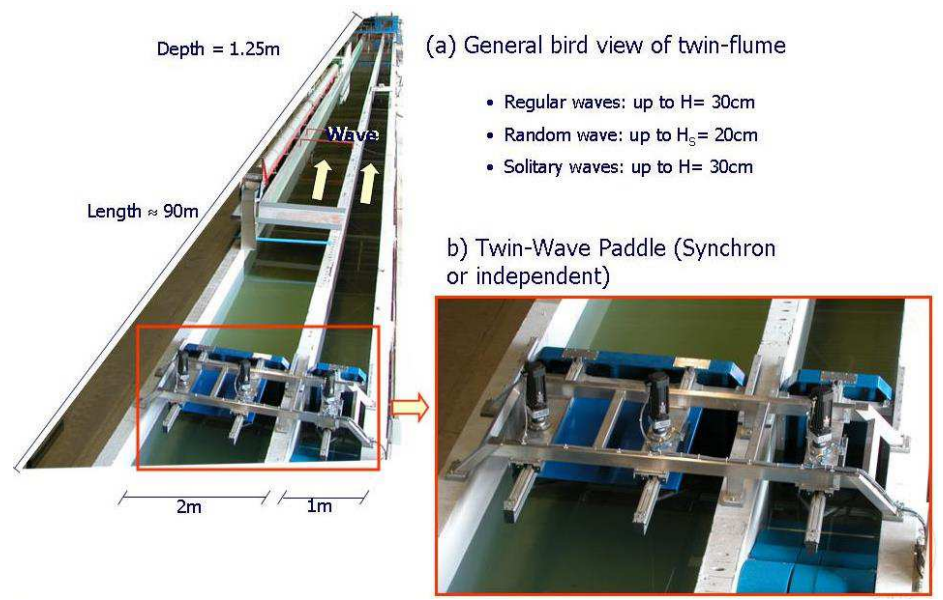

Figure 6. Twin wave flume at Leichtweiß-Institute für Wasserbau, Technical University Braunschweig.

Measurement devices comprise wave gauges at the paddle and near the structure, four pressure transducers on the crest wall, and wave overtopping measurements behind the highest parts of the revetment (Fig. 7). In addition, a video camera was used in order to provide a digital documentation of all tests.

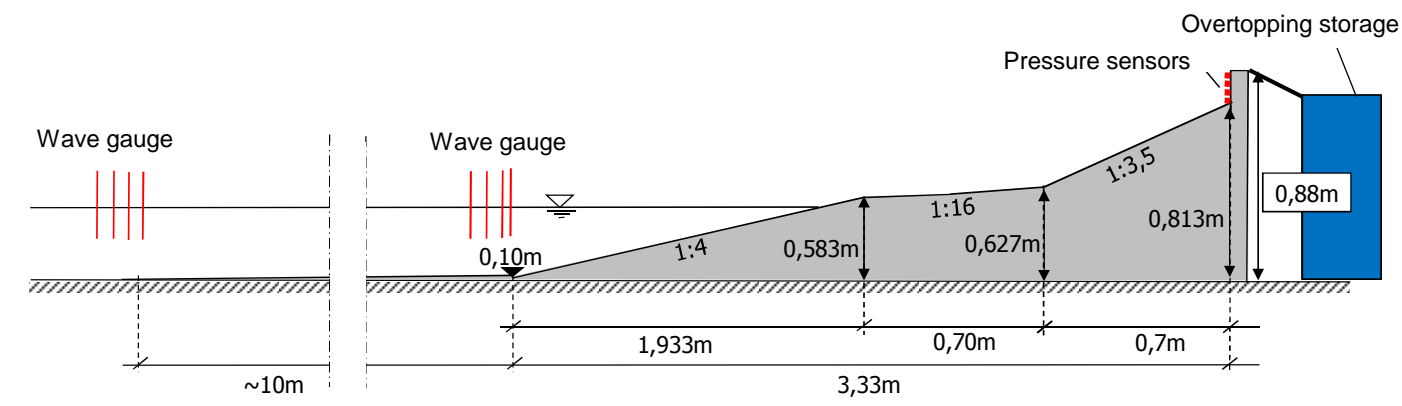

Figure 7. Overview of model and measurement devices.

Natural wave spectra and varying design sea state conditions along the construction obtained from the numerical modeling as well as JONSWAP wave spectra were taken into account. Additional regular waves were investigated in order to provide a comparison to the small scale tests.

A base model without wall elements and 5 variations concerning the shape and distance of the wall elements was investigated (Fig. 8). Main objectives of these tests were the optimization of the elements, the shape of the crest wall as well as determination of overtopping volumes and loading of the crest wall. The basic profile had a foreshore with a length of $10 \mathrm{~m}$. It was followed by a $1.90 \mathrm{~m}$ long $1: 4$ slope and a $0.70 \mathrm{~m}$ long berm with an inclination $1: 16$. The berm consists of an approximately $0.09 \mathrm{~m}$ horizontal section, on which the variations of wall elements were fixed. The model ends with $1: 3.5$ slope and a $0.07 \mathrm{~m}$ high vertical crest wall.

The investigated variations of the wall elements consider $1.5 \mathrm{~m}$ long and $0.8 \mathrm{~m}$ thick elements with a distance D1 $=0.5 \mathrm{~m}$ and $\mathrm{D} 2=0.75 \mathrm{~m}$. Heights of $0.5 \mathrm{~m}, 0.75 \mathrm{~m}$ and $1 \mathrm{~m}$ and additional $0.5 \mathrm{~m}$ high platforms as seating facilities for tourists. 


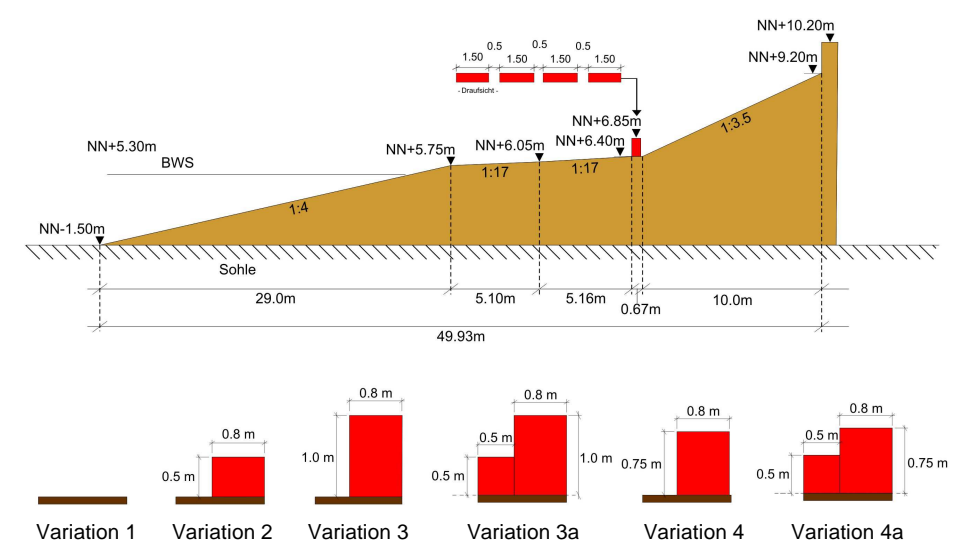

Figure 8. Investigated variations of wall elements.

Experiments for further optimization of the profile were executed in the $1 \mathrm{~m}$ wave flume. Here upper slope consists of two different inclinations. Additionally roughness elements at the upper slope as well as were elements and crest wall with wave return were investigated. In overview over the test program in the twin wave flume is given in Fig. 9.

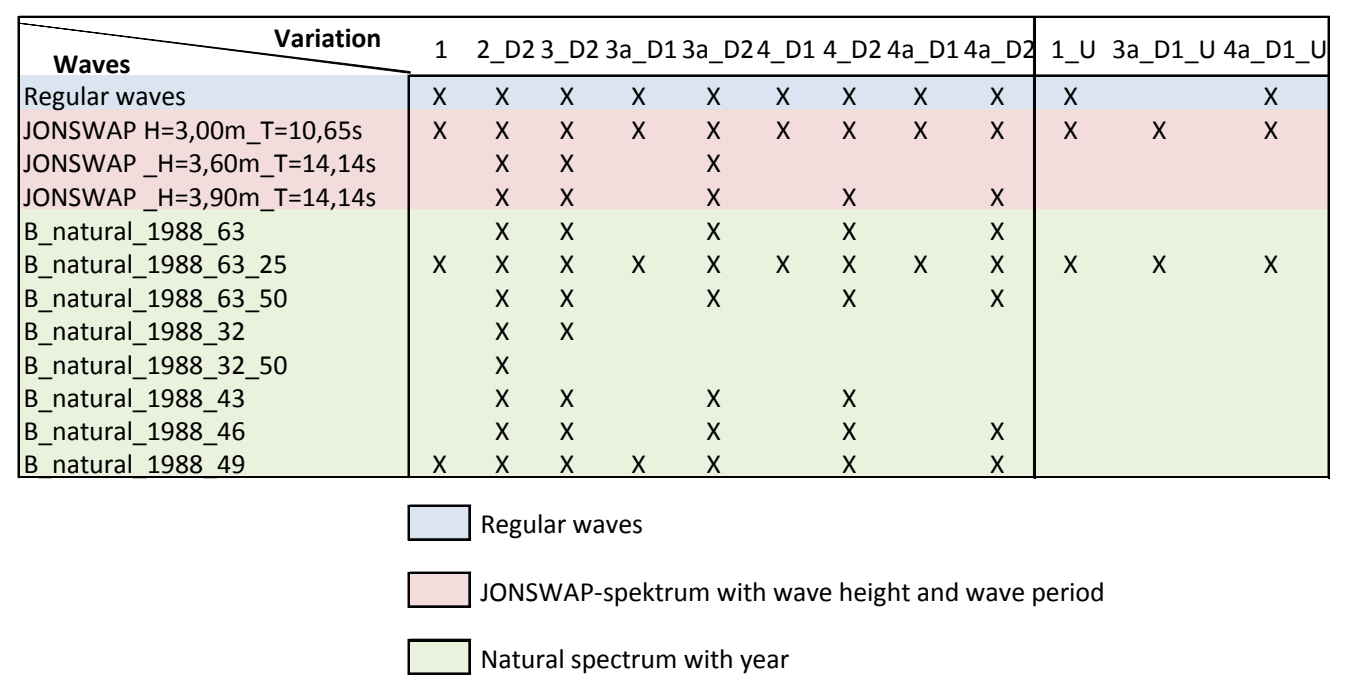

4a_D1_U Investigated Variation and spacing D1 or D2 and return wall U

\section{Figure 9. Test programme.}

A summary of the test results concerning overtopping performance is shown in figure 9 . Highest overtopping rates were measured for variation 1 without wall elements with figures of 10.7/20.1/20.0 $1 /(\mathrm{sm})$ for natural spectra/JONSWAP spectra/regular waves. Variation 2 with 0.5 high elements reduces overtopping to $42 \% / 68 \% / 51 \%$, Variation 3 with $1.00 \mathrm{~m}$ high elements to $24 \% / 36 \% / 14 \%$ and variation 3 with $0.75 \mathrm{~m}$ high elements to $42 \% / 40 \% / 19 \%$ (Fig. 10). Higher overtopping rates for the spectra were caused by the less favorable temporal sequence of the single waves and a higher proportion of waves with longer period compared to the natural spectra.

The stepped variations $3 \mathrm{a}$ and $4 \mathrm{a}$ showed in general higher overtopping rates, with can be explained by less roughness of the stairs. The application of a return wall shape for the crest wall can reduce overtopping significant up to a magnitude of ten. It has to be considered, that the model tests cannot reproduce the influence of onshore wind, which is present under design conditions and will lead to an increase of overtopping by waves and spray. 


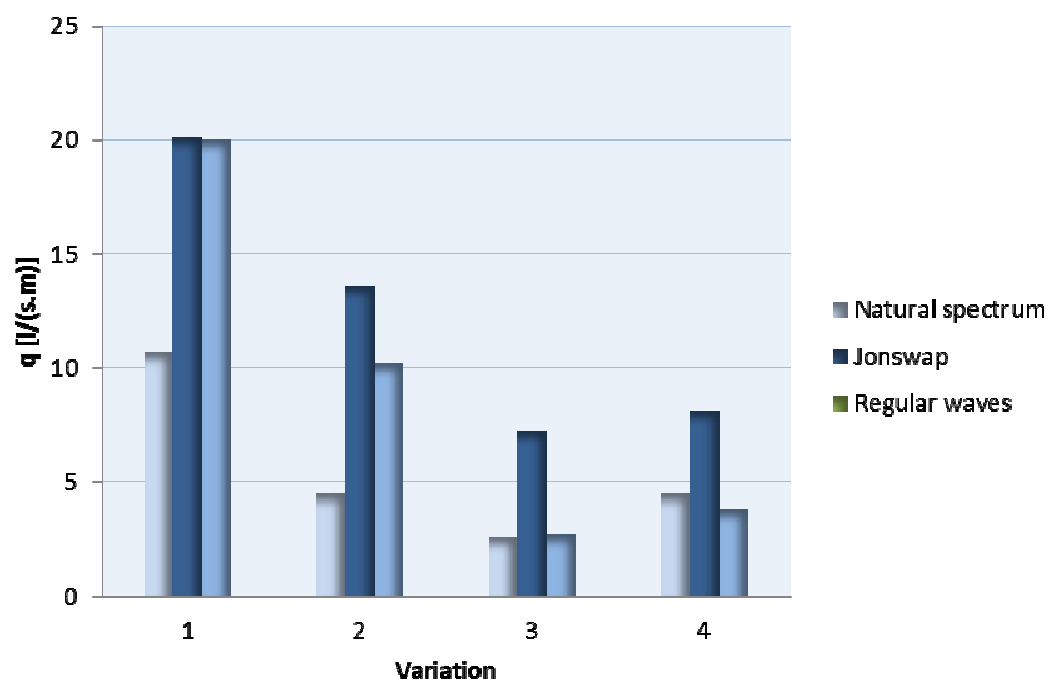

Figure 10. Overtopping rates for selected variations of wall elements and waves.

The crest wall is affected by waves breaking on the revetment. In order to evaluate the maximum resulting force at the crest wall $\mathrm{F}_{\max }$, measured pressures of the four pressure sensors PT1 to PT 4 (Fig. 7) were integrated over the crest wall height. At the time of maximum force, the respective pressures of PT 1 to 4 were determined as maximum pressures of the PTs. In the time series of pressure measurements higher loads are possible, but in these cases a lower total force on the wall occurs. The deviation of the maximum pressures during an entire time series of the pressures at the time of $F_{\max }$ amounted between $0.7 \mathrm{kPa}$ to $1.0 \mathrm{kPa}$ at pressures of up to $13.7 \mathrm{kPa}(7.3 \%)$. The maximum value of individual pressures at a time other than $\mathrm{F}_{\max }$ is therefore only slightly higher.

In addition to the obtained maximum values of the force $\mathrm{F}_{\max }$, the arithmetic mean of the $10 \%$ highest forces $\mathrm{F}_{1 / 10}$ were determined for each time series (Fig. 11). The difference between the two values can be considered as a measure of the difference between the maximum and the other heavy load events. Two forces can be seen, which are significantly higher than the values of the other forces. These two events could not be reproduced in a repeat of the tests. Due to their rarity and their physical development, these forces were considered not to be relevant for determination of the design force. As design force the upper boundary of the test results with $F_{\text {bem }}=90 \mathrm{KN} / \mathrm{m}$ was chosen.

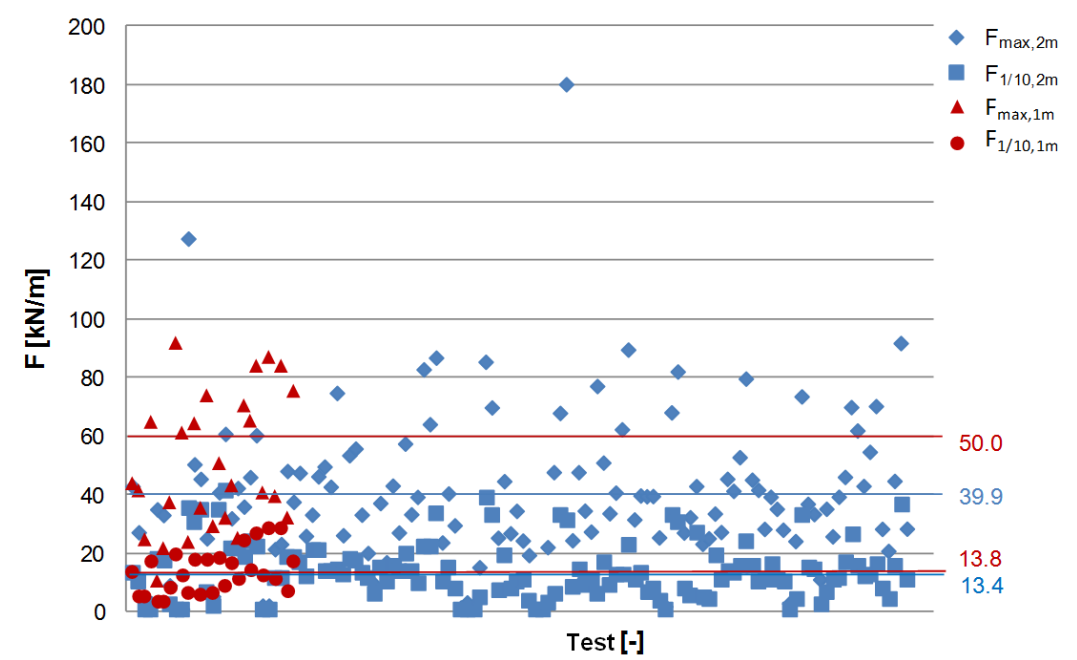

Figure 11. Calculated forces and comparison of $F_{\max }$ and $F_{1 / 10}$ for all tests (JONSWAP and natural spectra). 
Pressure shocks can be expected in case of a relative horizontal force $\mathrm{F}_{\max } / \mathrm{\rho gH}_{\mathrm{m} 0}{ }^{2}>2.5$. Since the highest ratio $\mathrm{F}_{\max } / \mathrm{ggH}_{\mathrm{m} 0}{ }^{2}$ determined out of the test series amounts to 1.8 , no pressure shocks are to be expected.

Design pressure distributions show in linear distribution for a vertical crest wall with decreasing values from bottom to top. In case of a return wall the pressures in the upper part of the wall are higher. The resulting design pressure distributions for both cases are shown in Fig. 12.
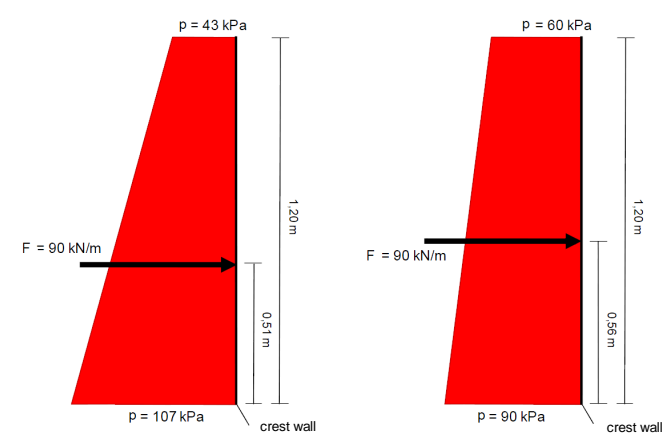

Figure 12. Design forces and pressure distribution at the crest wall without (left) and with (right) wave return).

\section{REVETMENT DESIGN}

Important boundary conditions for revetment design were on one hand the technical aspects resulting from the model tests and on the other hand the huge importance of the construction as part of the touristical infrastructure of the island. Within the $440 \mathrm{~m}$ long stretch, by a heightening of the construction and application of wall elements in combination with a crest wall, a significant reduction of overtopping to less than $5 \mathrm{l} /(\mathrm{s} \mathrm{m})$ can be achieved.

The planned design for the upper part of the revetment consists of $0.75 \mathrm{~m}$ high wall elements, consisting of a reinforced concrete construction with a sheet pile foundation (Fig. 12). A mantle of clinker bricks refers to the typical regional and local architectural style. For touristical demands, each fourth element has a height of $0.5 \mathrm{~m}$ and can be used as a seating device for tourists. In the model tests, no negative effects on wave overtopping have been measured. Directly adjoining the elements, an impermeable 1: 3 sloped granite revetment with additional $20 \mathrm{~cm}$ high roughness elements in combination with a $1: 6.6$ sloped interlocked concrete block revetment form the connection to the $1 \mathrm{~m}$ high crest wall. This consists of a wave return shape. A pavement, which can be used by tourists as well as a disaster road in case of storm surges and an inner slope with an $80 \mathrm{~cm}$ thick clay layer marks the landward side of the revetment. A realization of the new construction is planned for the years $2012 / 2013$.

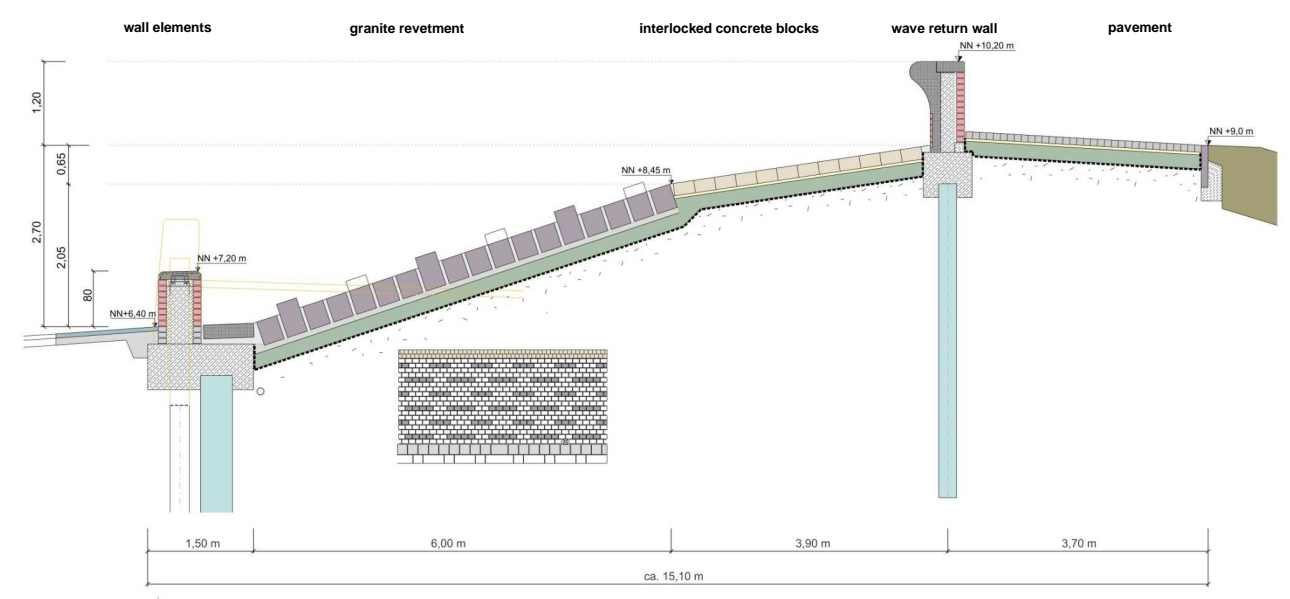

Figure 13. Final design of the upper section of the Baltrum dune revetment. 


\section{SUMMARY AND CONCLUSIONS}

The north-western part of the sandy barrier island Baltrum is protected by a dune revetment and groins against erosion and flooding due to storm surges. A safety check of functionality for design conditions of a $1 \mathrm{~km}$ long stretch of the dune revetment was executed. By means of combined hydronumerical modelling and large scale hydraulical model tests, design parameters for the construction were determined. The resulting wave-overtopping rates and pressure loads showed the need to heighten and strenghten significant parts of the construction. For a ca. $440 \mathrm{~m}$ long section no space for spatial extension of the revetment was available. Here a combination of wave run-up reduction elements consisting of a height of $0.75 \mathrm{~m}$, a width of $1.5 \mathrm{~m}$ and a crest wall of $1.0 \mathrm{~m}$ height was constructed in order to limit overtopping. Based on the model tests a technically functional and economical construction to guarantee flood and erosion protection was developed, which integrates demands of tourism and urban planning for the sea resort Baltrum (Fig. 14).

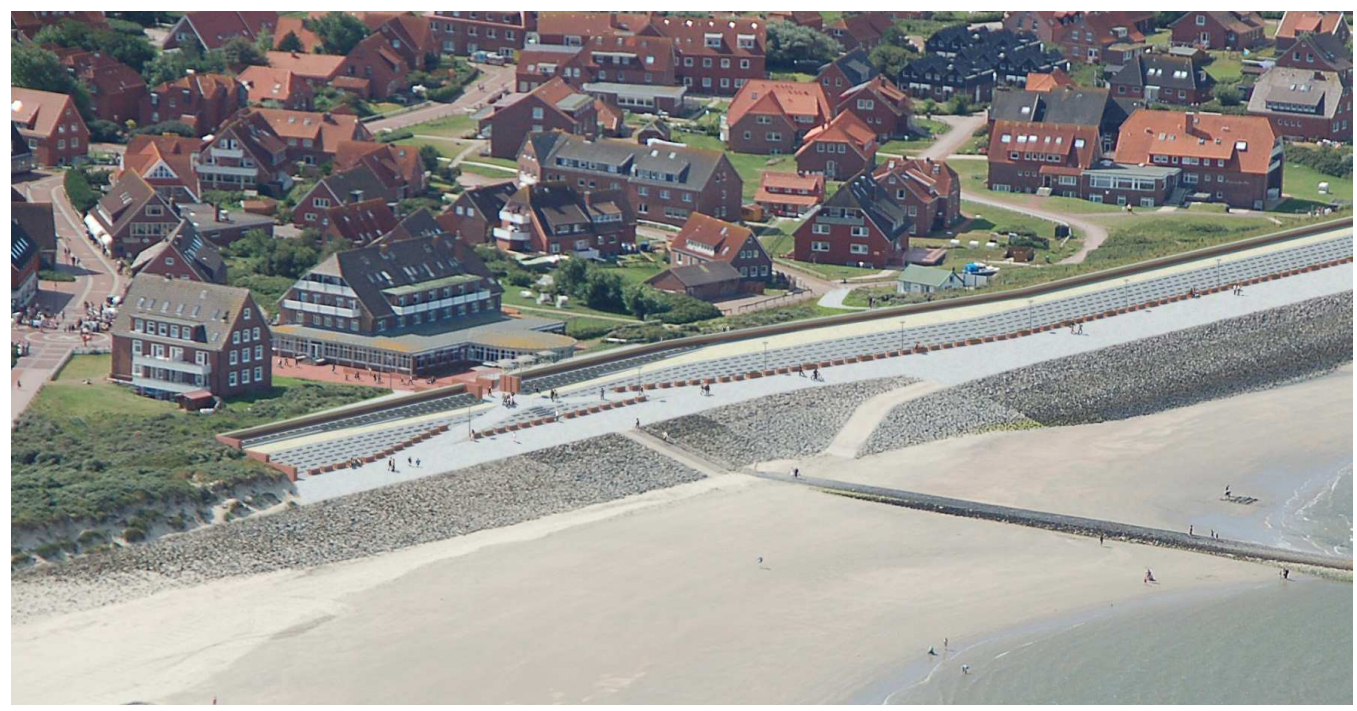

Figure 14. Computer visualization of the dune revetment.

\section{REFERENCES}

Blum, H., A. Kortenhaus, and F. Thorenz. (2008). Hydraulic Model Tests on Wave Overtopping Loading at a Historical Sea Wall Construction at Baltrum. Proceedings of $31^{\text {st }}$ International Conference on Coastal Engineering Hamburg, Germany.

Erchinger, H. F., and R. Ukena. 1987. Der Abbruch der Insel Baltrum bis zum Bau der Schutzwerke ab 1872, Ostfreesland Kalender für Jedermann 1987, Norden, Germany, 140 -147.

Kaiser, R. 2008. Bemessungsseegang für die Deckwerke am Weststrand von Baltrum, Kurzgutachten NLWKN, unpublished.

NLWKN. 2010. Master Plan Coastal Defence Lower Saxony - East Friesian Islands - Generalplan Küstenschutz Niedersachsen - Ostfriesische Inseln, Norden.

Oumeraci, H., A. Kortenhaus, S. Pförtner, S. Liebisch, H. Brodersen. 2011. Versuchstechnische Bearbeitung der Wellenüberlauf- und Wellenbelastungdes Deckwerksprofils 740 auf Baltrum. Bericht des Leichtweiß-Institut für Wasserbau, TU Braunschweig, Nr. 995, unpublished.

Liebisch, S., A. Kortenhaus, H. Oumeraci, F. Thorenz, and H. Blum. (2011): Wellenüberlauf und welleninduzierte Belastung des Deckwerks auf der Insel Baltrum, 8. FZK-Kolloquium - Maritimer Wasserbau und Küsteningenieurwesen, Forschungszentrum Küste, 69-74.

Thorenz, F., H. Blum. 2011. Implementing Coastal Defence Strategies for Sandy Coasts Reinforcement of the Norderney Dune Revetment, Proceedings 5th International Short Conference on Applied Coastal Research, Aachen. 